\title{
Dealing with Wicked Issues: Open Strategizing and the Camisea Case
}

\author{
Ruth Schmitt
}

Published online: 28 June 2011

(C) Springer Science+Business Media B.V. 2011

\begin{abstract}
The purpose of this article is to demonstrate, based on an extensive study of the Shell-led Camisea gas project in Peru, how what we believe to be a new approach to dealing with stakeholders, focusing on sense-making and combining industry dynamics and stakeholder empowerment, was developed. The project's success was measured by the fact that, unlike similar projects around the world, it did not meet with major opposition during its 4-year life span. Those involved in the Camisea project succeeded in creating an open approach to building stakeholder relationships, allowing them to navigate through a number of diverse and challenging socio-political and ecological issues. An integral part of Shell's approach was acting upon its commitment to high standards of operation and values. The insights from this case clearly indicate that stakeholder management and theorizing can profit from a less controlled, open and sense-making oriented strategizing with stakeholders.
\end{abstract}

Keywords Stakeholder relations $\cdot$ Stakeholder engagement $\cdot$ Strategizing

\section{Introduction}

The Camisea project, which we will present in this article, is a good example of how Shell managed the pressure created by increased public scrutiny and redefined its role in relation to adopting a more accountable and responsible

\section{R. Schmitt ( $\square)$}

School of Business, Institute of Management, University

of Applied Sciences Northwestern Switzerland,

Stahlrain 2, Brugg, 5200 Windisch, Switzerland

e-mail: ruth.schmitt@fhnw.ch approach to its gas exploration and production. The Camisea region, in which Shell's exploration activities took place, was both environmentally and socially sensitive. These factors created abundant issues that were subsumed under the question of how to develop the expected gas reserves in a manner that also supported a sustainable development of the Camisea region.

Nowadays, it is expected from companies starting projects of this scale to enter into an engagement process with their stakeholders. The hope is that projects like Camisea can be developed in concert with stakeholders and under the label of creating more stakeholder democracy in the sense of more self-governance and voluntarism (Matten and Crane 2005b). Democratic processes can produce a more participatory environment and can lead to shared responsibility and commitment. Implementing stakeholder engagements in practice, however, pose additional challenges for all involved; their potential to contribute to value creation both on the side of the company and the stakeholders is ambivalent (e.g. Bendell 2000, and for the oil industry, Idemudia 2009). In a better case, engagements can lead to shared responsibility, innovation and learning. The downsides, however, can be more stereotyping, more campaigning, more conflict, and in the worst case, lead to even more marginalization of local communities, for example.

Engaging with stakeholders means entering into a journey, the outcome of which is to a certain extent open, especially in situations that can be termed 'wicked' issues (Camillus 2008). These imply problems that reflect the characteristics of green-fields. They are complex, interdependent, with far reaching consequences for which there are no off-the shelf solutions. Furthermore, they interlink stakeholder groups who would otherwise not traditionally come together and require buy-in, the sharing of expertise as well as the competence and willingness to actually work 
together. Camisea exemplifies the aggravation of some of these characteristics, as the stakeholder environment of this project was quite dynamic, geographically dispersed, and the stakeholders involved were very diverse; this resulted in making it difficult for Shell to approach the Camisea stakeholders.

The goal of this article is to give a descriptive account of the Camisea case to show what it means for a company to enter into an open journey, which has potential deviations. It asks the question: what can be deemed to be an adequate form of strategizing in such a situation, which to a great extent is obstructive to a classical stakeholder management technique? This article postulates that the principle is to accept the risks of a less ordered and structured management approach in favour of implementing an open process which allows for sense-making, shared learning and shared power (Bryson and Crosby 1992).

The article will proceed as follows. It will provide a short introduction to the Camisea case and describe the nature of the issues with which Shell and its stakeholders had to deal. Secondly, it will briefly make reference to the analytical lenses used to study the Camisea case and the methodology applied in conducting the study. Thirdly, it will outline the new management scheme implemented by Shell. To impart an account of the principles, which should guide such an engagement, we will call this scheme 'open strategizing'. Finally, the article will critically discuss in the conclusion the case's contribution to theorizing about stakeholders and conducting engagements in practice.

\section{The Camisea Case}

The Camisea project, which provides us with a case for discussion, was a green field development conducted by Shell and was named after the region in which the operations took place. The project started in 1994 and ended in 1998 when Shell withdrew its activities there.

In 1994, Shell and Perupetro, Peru's government agency responsible for hydrocarbons, agreed to a new evaluation of the commercial potential of Camisea's gas fields (Anonymous 1994; May et al. 1999), as Peru was in desperate need of foreign capital and trade to stimulate its development. Shell Explorada y Productora del Peru BV (SEPP) discovered large reserves of non-associated natural gas in the $80 \mathrm{~s}$ and had at that time invested about 250 million US dollars in exploration.

At the time of Shell's earlier operations in Peru during the 80 s, no legislation or policies with respect to hydrocarbon exploitation, environmental protection or the protection of indigenous people existed. Shell's activities, similar to those of many other companies in other parts of the Amazon basin and elsewhere in the world, had resulted in disruptions both in the ecological and social environments, including deforestation, pollution of the natural environment, disturbance of communal lands and the introduction and spread of diseases among the local communities. As the company had been unable to reach an agreement with the authorities, it relinquished the fields in 1989, due to the lack of marketing prospects, the possibility of increasing critique related to its operations and the government's attitude of nationalizing the property of foreign companies (e.g. May et al. 1999; Post et al. 2002; Rozas 1997).

Under such circumstances which were connected to the region's sensitivity, the downsides of the earlier operations mentioned above and, as a result of a 2-year period of preliminary investigations between 1994 and 1996, it became obvious to Shell that the project would also need the support of a great variety of stakeholder groups, who had vested interests in the area.

Developing the Camisea fields was an extremely sensitive undertaking. The area lies in the upper Amazonian region of Peru, situated approximately $500 \mathrm{~km}$ east of Lima across the Andes in the Ucayali River Basin in the area of Cusco. The region is known as the Lower Urubamba (where the Urubamba River flows into the Ucayali river), and it borders the Manu national park, the largest area of undisturbed cloud forest in the world. It is rich in biodiversity and home to a number of indigenous people, primarily the Machiguenga. The Camisea area is also close to the Apurimac Reserved Zone, covering an area of $1,669,300$ ha and contains a similar range of biodiversity as Manu. Apart from the national importance of developing the gas reserves, the location of the Camisea area and the pipeline alone made it obvious that the project posed weighty environmental and societal considerations.

The Camisea project was finally stopped in the summer of 1998 after an extension of the initial license agreement, which had been signed in 1996. This, however, was not due to negative exposure vis-à-vis the national and international stakeholder community. In fact, the company succeeded with its stakeholder consultation program in that it received support from a majority of stakeholder groups, and most notably from its primary stakeholders, the communities. Even critical NGOs who generally objected to exploration in such sensitive areas as Camisea acknowledged that Shell had at least tried to do a good job.

The type of problems related to Camisea and, in the wider sense to sustainability, can be termed 'wicked' issues (e.g. Bryson and Crosby 1992; Camillus 2008). They are likely to have very long-term, unforeseeable consequences that go beyond a single project, region or time. Unforeseeable, because the problem itself is not yet well understood, measures are unclear and due to the practical impossibility of being able to make judgements about the risks involved by operations in such sensitive environments 
or the likelihood that they may even occur. The Camisea project could not be seen to be a venture under the control of a single company, nor of any of the other participating stakeholders. More exactly, dealing with the issue implied sharing power among the parties involved and required a solution process rather than a one-shot solution (Bryson and Crosby 1992). This was from Shell's point of view an adequate management approach for the Camisea project.

\section{Analytical Lenses}

We have used the Actor-Network Theory (Callon 1980, 1986; Harrisson and Laberge 2002) and Strauss' Negotiated Order Theory (Strauss 1978, 1988, 1993; Strauss et al. 1991) as analytical lenses. These theories were applied as they drew our analysis to the following points: both theories are constructivist in nature and preoccupied with sense-making activities. Furthermore, they stress the importance of dynamics and the provisional character of orders, and draw our attention to negotiation, which is a core activity in need of consideration.

Strauss' theory, especially his concepts of social worlds and arenas, describe how the parties involved fight out interests and definitions of reality. Social worlds are the more enduring aspects of situations which are expressed in terms of the ideologies, values, practices, etc., and which the members of a given world share. They influence their members, who are socialized in the respective social worlds and thus also limit their range of activities. In arenas, members of different social worlds come together to negotiate certain issues. Arenas are the more immediate contexts influencing interactions and are especially interesting in analyzing stakeholder engagements. Arenas can be formal but are more likely to be informal. In arenas, the stakeholders implement their strategies, which are directed at pushing through their claims and interests. The Negotiated Order Theory provides us with an understanding of the basic structure for the evolution of negotiated orders and thus also what we postulated would occur in the Camisea case. Understandings, agreements, rules and so forth have only temporal character; they need to be constantly worked on. Furthermore, they can be reviewed and renewed on a day-to-day basis but also within a framework of more longterm assessments of the status quo. Any interruptions impacting the negotiated order, such as, for example, new stakeholders, can break a negotiated order and result in new negotiations being necessary.

Actor-Network Theory, on the other hand, draws our attention to how the different stakeholders act as entrepreneurs in defining reality, selling or trying to impose their view of the world on to others. It provides us with a lens to more accurately identify the strategies the stakeholders use. The basic process through which a shared understanding is created is called 'translation', which denotes a dynamic process in which the identity of the involved actors, the possibility of interaction and the scope of agency are negotiated and aligned (Callon 1986). The process follows successive stages (Callon 1980) and, if it is successful, may end with other actors accepting those definitions of reality. Any of the actors involved in translation may put his vision through and also gain the support of other stakeholders for their project. Therefore, if we look at the Camisea case, we are aware that an actor-like Shell might be a successful Callonian entrepreneur who can attract stakeholders to its project, but this status is neither guaranteed nor can it be taken for granted.

Therefore, both analytical lenses, Negotiated Order Theory and Actor-Network Theory, make us look for actual strategies that were applied and the reasons as to why Shell was able to do so. Both theories make us aware that engagements cannot be controlled, and if ever, we have to look for how lasting any of the arrangements are. Everything is basically uncertain and reversible, and order and stability is more the exception than the rule (Callon 1986).

\section{Methodology for the Study Conducted}

Our study was an exploratory qualitative case study that followed an inductive strategy. The purpose of this combination was to inquire into a field that was not yet well developed (Yin 2008). This aimed at discovering the strategies used by one of the actors-in this case Shell-in dealing with the challenges mentioned in the previous section. We conducted a preliminary theorizing about how companies may deal with 'wicked' issue situations when the stakeholder environment is dispersed and fluid (Eisenhardt 1989). The study's methodology made reference to the grounded-theory approach (Strauss and Corbin 1990); its intent was to generate narrative statements relating to the phenomenon under study.

The methodological aspects can be outlined as follows: the Shell case was chosen on the grounds of a purposeful sampling strategy (Patton 2002). It provided us with an example for successfully dealing with a 'wicked' issue situation, in the sense that the project did not face major opposition during its life span. Data collection was based on interview data gathered from semi-structured interviews with both the Shell management in charge of Camisea and a selected set of stakeholders. ${ }^{1}$ To reduce the likelihood of misinterpretation, data collection was also based on

\footnotetext{
${ }^{1}$ Shell as well as the stakeholders interrogated have been providing the data for the study. All analysis and conclusions are the author's responsibility.
} 
secondary data, including historical as well as contemporary information. Secondary data comprised archival data, internal corporate documents, media releases and Internet sources. The data analysis was organized along the process of Shell's engagement. The focus was on the strategies Shell used in each of these phases and whether or not they were used with a different emphasis. We also looked for justifications for these strategies, both from Shell's side and also from the perspective of the stakeholders who were interviewed. Data analysis was performed according to the common procedures of inductive research and with the support of a computer tool called ATLAS/ti.

\section{The Camisea Case and Open Strategizing}

At the time of signing the license agreement, Shell had not only a fairly good understanding of the issues it was likely to face, but it had developed a very far-reaching stakeholder consultation process to provide the framework for negotiating with the government, as well as with other interested parties, on both national and international levels.

- It had to develop a clear understanding of its responsibilities and disassociate itself from any policy to open up the region for colonization.

- It had to secure the interests of the local indigenous people, to ensure that they were not exploited and that their rights and culture were protected.

- It had to develop clear environmental guidelines and policies, not only as to how they could develop measures against environmental impacts, but especially in relation to how it would deal with Manu National Park and the Apurimac Reserved Zone.

Due to its unfortunate past in the region during the 80s, Shell had made the decision to maintain an open and transparent process of participation even before the disposal of the Brent Spar storage buoy became imminent or the problems in Nigeria were elevated to a high profile (Jones 1997).

These problem areas called for the support of a diverse stakeholder environment that was difficult to involve for different reasons: first, it was under-organized and thus formalizing interactions was difficult if not, in certain respects, counterproductive. Second, there were stakeholder groups with different levels of expertise. Interaction therefore had to be sensitive and open to this diversity, and supportive of different forms of working together. Finally, the geographical dispersion of the groups involved and the sheer number of the stakeholder groups further aggravated the situation.

Taking into account the specifics of this stakeholder environment, we would like to demonstrate that many of the strategies Shell used were counterintuitive to what we have until now learned from classical stakeholder theory. Many of the strategies used added up to what we would call a very open form of strategizing, which we believe can influence discretion in any other 'wicked' issue situation. In applying our analytical lens to the case, we found strategies that will be explained in more detail below.

\section{Co-Construction}

Issue framing-or co-construction-is a vital task when dealing with 'wicked' issues since the way an issue is framed has a considerable impact both on the stakeholders around it and their perceptions of the meaning of the proposed solutions (Bryson and Crosby 1992).

Now, the funny thing was that the workshop facilitator asked stakeholders to get people going, you know, kind of, 'this project is seen as a 40-year project'. It would probably be longer than that, but you know, if it was seen as a 40 -year project, what would their wishes for the region be in 40 years time. Well, the environment remains intact, if you like, the communities have reached a level of development that they would want but do not feel imposed upon by externals. It was basically about sustainable development. So in the debate the facilitator got people to do a mind map on the wall. And funnily enough, the mind maps, I think between all the workshops, were quite consistent. (Interview with B, February 1999)

As all of the co-construction activities took place in the light of a demanding project, touching also some of the more fundamental values, co-construction was always a matter of identity preservation and enrolling in a shared understanding of the situation (Harrisson and Laberge 2002). Of course, there were rival interpretations of what Camisea should be, and they remained throughout the project but did not touch the engagement process fundamentally. It appeared important, however, that these differences were treated in a respectful manner and that they remained on the radar throughout the process. As the above citation indicates, there was relatively quickly a more or less consistent framing of what the Camisea project should be, and the framing could be successfully maintained.

Related to co-construction, we have identified the following sub-strategies: listening and learning, and empowerment.

Co-construction implied that rather than proceeding with speed and reducing complexity, which would pertain to a management logic, stakeholder needs needed to be fully understood even if this required time. This was vital because in the case of a 'wicked' issue, none of the parties involved has the knowledge to resolve it on its own. So, 
rather than following cost-benefit considerations to conclude the project quickly, it was about gaining informational richness. Shell thus started relatively early to intensely listen to any concerns. The primary value of this was that-even though resource intensive-listening and learning generated new ideas and new ways of approaching the case.

We didn't have all the answers, you know, we just didn't have all the answers. And I think there isn't anything wrong with stopping there and saying, 'We don't have all the answers. Can you help us?' And I think that changed the dynamic. You've seen the thing and you decide on the project, you announce the project and then you defend it. (Interview with B, February 1999)

The second sub-strategy related to co-construction related to empowerment. Regarding the diversity of stakeholders, not only in terms of their institutional forms, but also in terms of the level of expertise, empowerment was a vital element. Projects in the oil and gas industry presuppose a general technical literacy to participate in consultation, but also literacy in other respects, i.e. in questions of sustainable development, environmental questions, legal questions, intercultural questions and so forth. We found, for example, that even some of the environmental groups had difficulties following the technical terms of an environmental impact assessment, let alone lay groups.

Shell and Mobil would come and say, 'Well, these plans are out there for review three months, 45 days, whatever. Everybody can make comments. But we're not getting any comments. How do we interpret that? Does that mean that all these stakeholders are happy, that this is a good plan? Or what does it mean?' And of course it didn't mean that. What it meant was that despite the fact that there's publicity on these things, a lot of people didn't know about it. The other thing was that even if you know about it, you get this huge impact assessment and management plan for the area. But it required a lot of technical knowledge to judge whether it's good or bad or whether it is deficient or whatever it might be. (Interview with C, October 1999)

The communities and other relevant stakeholders were a critical mass who needed to be enabled to participate in interactions. Nevertheless, if they were unable to develop the necessary capacities, it would threaten the sustainability venture as a whole (Callon 1986). Furthermore, stakeholders could only participate if the resources were available, and some also needed empowerment in this respect. Empowerment and capacity building is a multidimensional social process that needs to be defined together and helps people to engage in self-defined action (Page and Czuba 1999; Schwerin 1995). Hence, what we could primarily see develop in the Camisea case was that the company started to effectively and increasingly act as a facilitator to help build and open networks to the players who could provide the necessary empowerment (e.g. Ramiller 2005). It was important for the company to identify adequate institutions or individuals who possessed the right qualities, capabilities and operational approaches to successfully provide the basis for capacity building and empowerment.

\section{Shaping Arenas}

Arenas can be understood as areas of dispute, rather than simple geographical locations, where the stakeholders come together to debate, negotiate, fight-out, force or manipulate issues (Strauss 1978). A practical example for a more formal arena is a roundtable, but also virtual discussion forums may be considered as an arena. We will first start with describing two sub-strategies, which we believe belong together and should be subsumed under the overarching term. They are called setting the criteria for the process and structuring.

The first of the sub-strategies is related to setting a number of criteria under which the process of engagement should take place and also under what rules of the game the parties are going to meet in the various arenas. Shell set up criteria for a process to which it adhered to itself. It expected this commitment would bear unforeseeable outcomes, but it intended to remain open, permanent and transparent to all the parties involved.

Yes, OK, it emerged, that is what I am saying, these things began to emerge in terms of saying it is one thing to say you must consult, which is sort of the byline, and then to say now what are we going to do in this place. And so it happened as it happened, it emerged as we went along. We didn't have a clear pathway through this except to set maybe some very, very key principles at the beginning and virtually one of the earliest things we kept saying to ourselves and to each other was that we have to be open and transparent. That became kind of a theme, an underlying core theme, to anything and which we did. And that kind of dictated when you got into a scenario that said should we go this way or that way or which was the way that was open and transparent, so you could test it against a certain principle. (Interview with A, March 1999)

The second sub-strategy related to the first, but with a different emphasis. It is called structuring, which comprises of finding ways to structure a process which is not manageable in the classical sense (Callon 1986). The most 
prominent among the devices that structured the process was the adaptive environmental impact assessment which was an integral component of the Camisea project, but there were also the briefing papers, reports, studies, etc., which served as a means to solidify the system of interactions with reliability. They are more suitable for 'wicked' issue settings that call for adaptive and flexible forms of ordering than other more formal forms of ordering (Law 1992).

I think another thing is being able to provide multiple media for the message, the website, full documentation, summary reports, briefing papers, meetings, workshops, you need a range of approaches. I think we learned that it is a process, it is not an event so that you have to start being engaged and then you have to be willing not only to work at your pace but also at the pace and the desire of the people you are talking to, so that you don't say we are having an open house next week and after the open house we will sign a contract, that is insufficient, of course. (Interview with A, March 1999)

We believe that in dealing with 'wicked' issue settings and with a great variety of stakeholders, being skilful in designing and using arenas is decisive to successful strategizing. It is to some extent a material matter of creating the measures named above, ordering them adequately and linking them with the actors involved so that they allow for co-construction and self-organization and further adaptation to outside dynamics. Furthermore, the arenas should be created such that no relevant party is closed out. The technical protocols, workshops, documents, impact assessments, all contribute to the patterning of the relations with the stakeholders, but only when these single elements are combined in a meaningful and supportive manner (Callon 1992).

Shaping arenas is an interactive process. If they are defined, one also has to be aware that arenas can develop different dynamics, which need to be considered. What were the reasons for focusing on arenas? It provided Shell with an opportunity to contribute to a process, which necessitated openness in terms of content but was not fully manageable. None of the stakeholders who participated on the level of an informed consent would agree that they were forced into opinion-building that was predefined. Rather, in providing the stakeholders with an open texture for interaction, Shell was able to build relations with their stakeholders, even when they were adverse, that lasted longer than the Camisea project.

\section{Credibility}

Credibility was a relevant theme to all, but especially to Shell, which as a first mover with a newly defined role, was especially under scrutiny and challenged to nurture this major asset (Worden 2003). Therefore, we saw credibility as a passage point through which the other two strategies with their sub-strategies-co-construction and influencing the arenas - needed to be validated. That is, credibility was itself seen as an asset to be nurtured, but it was also a type of an indicator related to if, and to what extent, the stakeholders accepted any moves from the side of Shell. Thus, influencing the arenas and co-construction could only be performed under company leadership if the others perceived the company to be credible.

By credibility we mean the extent to which a company is perceived to have the knowledge and the ability to fulfil its claims and if it can be trusted or not (Newell and Goldsmith 2001). Credibility therefore lies in the eye of the beholder. In order to be perceived as credible, the company needed to translate words into deeds (Worden 2003). However, the credible company also needs to have integrity and to have and maintain strong core values with high standards of operation (Waddock 2001). In this sense, acting with stakeholders in 'wicked' issue settings cannot be mere public relations exercises of a company. It implies that there is 'a judicious mix of candour, competence and performance' (Higgins and Diffenbach 1989, p. 17). Credibility in the Camisea case was always under potential threat. This was, for example, true because contractors in the supply chain might not support Shell's approach to a sustainable project.

I think at the former stages you have the greatest chance to influence and that is when you want to get the criteria right. It is this criteria which becomes the governing criteria throughout and were going to be the criteria in the next phase when we actually built the project-probably the most difficult phase on the ground, but still the criteria were the same. And so if we hadn't had the criteria and the policies, there is no way that we could have convinced the contractor what he had to do. We had to have that. At that phase I think the next real big phase is getting it done on the ground so whenever we start doing something on the ground you are delivering what you said you would deliver. (Interview with A, March 1999)

To be perceived as credible, the company had to be reliable at any time in the project's duration, implying that its personnel supported the commitments made, but also that it could mobilize the external stakeholder environment to the extent that its commitments were not endangered.

Shell found different answers to these challenges, which can be understood to have been successful in the Camisea case. First, very early on, the company decided to be open and transparent in dealing with information and they also acknowledged the concerns expressed by stakeholder groups, and did not exclude any of them. This is illustrated by a quote of an NGO: 
Well, there were several things. One is honesty. You cannot hope to bring organizations like ours-and we're not the most aggressive - on board in a dialogue unless perceived as being honest. Which means that you have to overcome the natural reluctance to share information that typically for these types of companies has been confidential information because up until recently environmental best practices and social best practices had been viewed as giving the company a competitive edge over other companies. We need to break down the competitiveness and therefore be much more open and forthcoming with information. And Shell tried that in a very big way. (Interview with C, October 1999)

Credibility also meant to not only communicating success, but also being honest about failures and mistakes, and amending them as a consequence. Furthermore, it meant that external parties were informed about company moves and were able to understand them well.

Finally, it was also important for Shell to demarcate its own role as opposed to the role of others involved, and to communicate this clearly and openly to external parties as highlighted by the quote below.

Provide a clear definition of the role and scope of accountability of Shell and other interested parties in the project including Perupetro and the Peruvian Government. (written document)

Every participant had to understand its share of responsibility. Putting this through was at times a challenge. Maintaining credibility, with all its sub-strategies, is a vital activity to keep a process going in which various stakeholders for diverse reasons may not be able to contribute to their predefined tasks. In the case of Camisea, which was closely related to the development of the region, Shell was thrown into a situation whereby it would potentially take over tasks that should have been performed by others (e.g. the local government) and of contending with increasing critique towards them for not being legitimately allowed to do so.

To summarise our idea regarding 'open strategizing': it is our opinion that the essence of this type of strategizing is that, instead of trying to dictate directly what people should or should not do, one should try to follow a process of logic, creating the conditions which enable interaction and to encourage arrangements for coping with issues, acting as a facilitator, coach and team player. This is a new mindset that differentiates itself from a purely instrumental managerial logic.

\section{Reflections}

Shell had developed a successful scheme-'open strategizing'-in dealing with project-related challenges, a scheme that can also form new theory building and new modes of practice relating to stakeholders. This scheme emphasizes the fact that stakeholder engagements, especially in the situation of a 'wicked' issue, evade a fully ordered approach and call for dialogue, sense-making and a more balanced stakeholder participation as well as governance mechanisms that help companies to successfully navigate through challenges (e.g. Payne and Calton 2002).

Classical stakeholder theory comprises an abundance of work that has a strong managerial focus and is built up on the ground of what we called a 'conventional steering model' (Savage et al. 1991). In this inside-out model, complexity is reduced in favour of increased conceptual clarity, however, at the cost of depicting the multiple casualties and dynamics underlying stakeholder relations. That is, we observe an inherent trade off between 'clean' theorizing versus dealing with paradoxical and complex situations.

Taking a retrospective view of the company and what it reported to have encountered in the Camisea case, we found repeated expressions among their quotes such as 'we did not know the solutions', 'we did not have any predefined management plan', 'it was not up to us to tell themthe stakeholders-what to do', etc. Yet, from the view of the company as an efficiency-driven entity, they would have required some sort of ordered approach. That is, Shell was neither able to fully adhere to the wishes and concerns of the groups nor could it just simply follow its own plans. Thus, the pressure was always connected to prevent it being perceived as operating from behind a façade, resulting in the stakeholder environment judging the company's endeavours as non-authentic or losing itself in dialogues while attempting to follow all of the interests of the stakeholders concerned. We therefore discovered that management did not follow a rigidly structured management plan; central steering was not possible because the tasks of governance were complex and difficult, and no single organization could perform them all (Bryson and Crosby 1992). Therefore, non-routine strategy-making emerged as participants acted on the issues at hand.

Our approach assumes that dynamics are an integral part of 'wicked' issue situations and thus there should also be a theoretical body accounting for these dynamics. Hence, it is impossible for a single organization to be in charge of the substantive problems that require resolution. Furthermore, a company cannot follow a rigidly structured planning process that promises to be successful. In these environments, a single organization is hardly in a position to determine outcomes and governance implies more than this. In projects such as Camisea, leaders empower themselves and their stakeholders to associate with others in dealing with their environments while sharing responsibility. Leadership is about coping with informational 
richness, establishing rules for the game to which the parties addressed can adhere, and about structuring a process that permits self-governance and self-reliance. In order to advance theorizing on stakeholders in such settings, it is important that we understand more about the sense-making activities of the parties and identify the other schemes for dealing with 'wicked' issue situations which may occur on the grounds of constructivist theories as mentioned above (Nijhof and Jeurissen 2006; Pasquero 1996). These theories open our eyes to new forms of engagement that develop in the field.

Camisea as it was conducted by Shell offers a descriptive account of business practices in a multinational context. It is an example of how a corporation-among other issues - was thrown into a situation in which it had to take on new roles, among them administering to a certain extent, citizenship rights that would have otherwise been the original task of the national and local governments. This of course raises to date unanswered questions of legitimacy about such a newly adopted corporate role (Matten and Crane 2005a; Scherer and Palazzo 2008). More so, we find increasing critique that corporate social responsibility initiatives may not only be ineffective in reaching the desired positive impacts but, for example, may even lead to more marginalized local communities and destroyed environments (Sawyer and Terence Gomez 2008). This article has not addressed these critical issues in depth, but it is our wish to highlight them and emphasize the importance of defining new forms of stakeholder governance that respect the question of legitimacy and the political nature of business operations and ultimately lead to true democratization. This is especially relevant with regard to the fact that the Camisea project took a very disadvantageous trajectory both for the communities and for the environment after Shell had left. As projects as Camisea are so huge in scale, they can develop a momentum that can hardly be stopped once set off which also became clear with the recent BP desaster. We should not forget enforce our efforts for multi-disciplinary views on stakeholder democracy and link them to the relevant arenas for a sustainable development that deserves the name (Blowfield and Frynas 2005; Frynas 2008; Idemudia 2009).

We believe 'open strategizing'-and with it the theoretical body sustaining it-is especially important in triggering new views regarding stakeholder practice and theorizing. The approach cannot handle all the implications a case such as Camisea would suggest in terms of fully responding to the corporate social responsibility challenges. However, it can be the door-opener for more innovative practices to occur as instrumental and management-driven approaches are too short-sighted for these 'wicked' issue situations. If true value creation is to take place and companies are to play a role in actively participating in value creation, they need to understand the underlying logic of such engagements, other than just following a check-list style of establishing engagements. 'Open strategizing' highlights the capabilities that should be developed on the company side.

\section{References}

Anonymous. (1994). Shell to study development of Peru's Camisea gas/condensate. Oil and Gas Journal, 92(13), 32.

Bendell, J. (2000). Talking for change? Reflections on effective stakeholder dialogue. New Academy of Business Innovation Network (online). Retrieved September 18, 2009, from http://www.new-academy.ac.uk/publications/keypublications/ documents/talkingforchange.pdf.

Blowfield, M., \& Frynas, J. (2005). Setting new agendas-Critical perspectives on corporate social responsibility in the developing world. International Affairs, 81(3), 499-513.

Bryson, J. M., \& Crosby, B. C. (1992). Leadership for the common good-Tackling public problems in a shared power world. San Francisco, CA: Jossey-Bass Publishers.

Callon, M. (1980). Struggles and negotiations to define what is problematic and what is not. In K. Knorr, R. Krohn, \& R. Whitley (Eds.), The social process of scientific investigationSociology of the sciences (Vol. 4, pp. 197-219). Dordrecht and London: D. Reidel Publishing Company.

Callon, M. (1986). Some elements of a sociology of translationDomestication of the scallops and the fishermen of St Brieuc Bay. In J. Law (Ed.), Power, action and belief (pp. 196-233). London: Routledge \& Kegan Paul.

Callon, M. (1992). The dynamics of techno-economic networks. In P. S. R. Coombs \& V. Walsh (Eds.), Technological change and company strategies-Economic and sociological perspectives (pp. 72-102). San Diego, CA: Harcourt Brace Jovanovich Publishers.

Camillus, J. (2008). Strategy as a wicked problem. Harvard Business Review, 86(5), 99-106.

Eisenhardt, K. M. (1989). Building theories from case study research. Academy of Management Review, 14(4), 532-550.

Frynas, J. (2008). Corporate social responsibility and international development-Critical assessment. Corporate Governance, 15(4), 274-281.

Harrisson, D., \& Laberge, M. (2002). Innovation, identities and resistance-The social construction of an innovation network. Journal of Management Studies, 39(4), 497-521.

Higgins, R. B., \& Diffenbach, J. (1989). Strategic credibility-The basis of a strong share price. Long Range Planning, 22(6), $10-18$.

Idemudia, U. (2009). Oil extraction and poverty reduction in the Niger delta-A critical examination of partnership initiatives. Journal of Business Ethics, 90(1), 91-116.

Jones, M. (1997). The role of stakeholder participation-Linkages to stakeholder impact assessment and social capital in Camisea, Peru. Greener Management International, 19(3), 87-97.

Law, J. (1992). Notes on the theory of the actor network-Ordering, strategy and heterogeneity. Retrieved December 15, 2003, from http://www.comp.lancs.ac.uk/sociology/papers/Law-Notes-onANT.pdf.

Matten, D., \& Crane, A. (2005a). Corporate citizenship-Toward an extended theoretical conceptualization. Academy of Management Review, 30(1), 166-179. 
Matten, D., \& Crane, A. (2005b). What is stakeholder democracy? Perspectives and issues. Business Ethics: A European Review, 14(1), 6-13.

May, P., Dabbs, A., Fernandez-Davila, P., Gonçalves da Vinha, V., \& Zaidenweber, N. (1999). Corporate roles and rewards in promoting sustainable development-Lessons learned from Camisea. Berkeley, CA: Energy and Resources Group, University of California, Berkeley.

Newell, S. J., \& Goldsmith, R. E. (2001). The development of a scale to measure perceived corporate credibility. Journal of Business Research, 52(3), 235-247.

Nijhof, A., \& Jeurissen, R. (2006). A sensemaking perspective on corporate social responsibility-Introduction to the special issue. Business Ethics: A European Review, 15(4), 316-322.

Page, N., \& Czuba, C. (1999). Empowerment-What is it? Journal of Extension, 37(5) (online). Retrieved September 15, 2009, from http://www.joe.org/joe/1999october/comm1.html.

Pasquero, J. (1996). Stakeholder theory as a constructivist paradigm. Proceedings of the international association for business and society, Seventh annual conference, Santa Fe, NM, pp. 584-589.

Patton, M. Q. (2002). Qualitative evaluation and research methods (3rd ed.). Thousand Oaks, CA: Sage Publications.

Payne, S. L., \& Calton, J. M. (2002). Towards a managerial practice of stakeholder engagement-Developing multi-stakeholder learning dialogues. In J. Andriof, S. A. Waddock, B. W. Husted, \& S. Sutherland Rahman (Eds.), Unfolding stakeholder thinking (pp. 121-135). Sheffield: Greenleaf Publishing.

Post, J., Preston, L., \& Sachs, S. (2002). Redefining the corporationStakeholder management and organizational wealth. Palo Alto, CA: Stanford University Press.

Ramiller, N. (2005). Applying the sociology of translation to a system project in a lagging enterprise. Journal of Information Technology Theory and Application, 7(1), 51-76.

Rozas, U. (1997). Umweltschutz vor Menschenrecht? Erdölexploration im Madre de Dios (Peru) im Spannungsfeld von Profit, Naturschutz und indigenen Rechten. Infoe Magazin, Zeitschrift für Ökologie und "vierte Welt”, 12(1), pp. 24-27.
Savage, G. T., Nix, T. W., Whitehead, C. J., \& Blair, J. D. (1991). Strategies for assessing and managing organizational stakeholders. Academy of Management Executive, 5(2), 61-75.

Sawyer, S., \& Terence Gomez, E. (2008). Transnational governmentality and resource extraction-Indigenous peoples, multinational corporations, multilateral institutions and the state, identities, conflict and cohesion programme. Paper Number 13, United Research Institute for Social Development.

Scherer, A. G., \& Palazzo, G. (2008). Corporate citizenship in a globalized world-Introduction to the handbook of research on global corporate citizenship. In A. G. Scherer \& G. Palazzo (Eds.), Handbook of research on global corporate citizenship (pp. 1-21). Cheltenham: Edward Elgar Publishing.

Schwerin, E. (1995). Mediation, citizen empowerment and transformational politics. London: Praeger.

Strauss, A. (1978). A social world perspective. In N. K. Denzin (Ed.), Studies in symbolic interaction (Vol. 1, pp. 119-128). Greenwich: JAI Press Inc.

Strauss, A. (1988). Negotiations-Varieties, contexts, processes and social orders (4th ed.). San Francisco, CA: Jossey-Bass.

Strauss, A. (1993). Continual permutations of action. New York: Aldine de Gruyter.

Strauss, A., Bucher, R., Ehrlich, D., Sabshin, M., \& Schatzmann, L. (1991). Negotiated order and the coordination of work. In A. Strauss (Ed.), Creating sociological awareness (pp. 3-32). New Brunswick, NJ: Transaction Publishers.

Strauss, A., \& Corbin, J. (1990). Basics of qualitative researchGrounded theory procedures and techniques. Thousand Oaks, CA: Sage Publications.

Waddock, S. (2001). Integrity and mindfulness. In J. Andriof \& M. McIntosh (Eds.), Perspectives on corporate citizenship (pp. 26-38). Sheffield: Greenleaf Publishing.

Worden, S. (2003). The role of integrity as a mediator in strategic leadership-A recipe for reputational capital. Journal of Business Ethics, 46(1), 31-44.

Yin, R. K. (2008). Case study research-Design and methods (4th ed.). Beverly Hills, CA: Sage Publications. 